УДК 616.831 - 005.1:616.13-007.64-089-092.11

\title{
С. О. Дудукіна
}

\section{Вплив штучної гіпотермії та симвастатину на стан когнітивних функцій у хворих з інтракраніальними аневризматичними крововиливами} Дніпропетровська обласна клінічна лікарня ім. І.І. Мечникова

Ключові слова: інтракраніальні крововиливи, когнітивні функції, симвастатин, гіпотермія.

Вплив методів запобігання та лікування вторинної ішемії мозку, зокрема симвастатину та гіпотермії, на стан когнітивних функцій вивчений недостатньо. 3 метою оцінювання впливу альтернативних методів запобігання та лікування вторинної ішемії мозку в пацієнтів з інтракраніальними аневризматичними крововиливами на якість життя після операції за шкалою MMSE визначили стан когнітивних функцій при виписуванні зі стаціонару, через 6 місяців і 2,5 року після лікування. Встановили, що використання профілактичної гіпотермії та симвастатину на стан когнітивних функцій майже не впливає. Використання терапевтичної гіпотермії у пацієнтів з інтракраніальними аневризматичними крововиливами, що ускладнились вторинною ішемією мозку та внутрішньочерепною гіпертензією, призводить до покращення когнітивних функцій, зокрема функції орієнтиру, пам’яті, мовленнєвих функцій, читання та послідовності виконання вправ, особливо через 2,5 року після оперативного втручання.

\section{Влияние гипотермии и симвастатина на когнитивные функции у пациентов с интракраниальными} аневризматическими кровоизлияниями

\section{С. А. Дудукина}

Влияние методов профилактики и лечения вторичной ишемии мозга, а именно симвастатина и гипотермии, на состояние когнитивных функций изучено недостаточно. С целью оценки влияния альтернативных методов профилактики и лечения вторичной ишемии мозга на качество жизни у пациентов с интракраниальными аневризматическими кровоизлияниями после операции по шкале MMSE определили состояние когнитивных функций при выписке из стационара, через 6 месяцев и 2,5 года после лечения. Установлено, что применение профилактической гипотермии и симвастатина не влияет на состояние когнитивных функций. Применение терапевтической гипотермии пациентов с осложненным течением интракраниальных аневризматических кровоизлияний улучшает когнитивные функции в послеоперационном периоде, в частности функции ориентира, памяти, речи, чтения, последовательности выполнения команд, особенно через 2,5 года после оперативного вмешательства.

Ключевые слова: интракраниальные кровоизлияния, когнитивные функиии, симвастатин, гипотермия.

Запорожский медицинский журнал. - 2015. - №2 (89). - С. 31-36

\section{Influence of artificial hypothermia and simvastatin on cognitive function in patients with intracranial aneurism hemorrhages}

\section{S. O. Dudukina}

Aim. Influence of prophylactic and treatment methods of secondary brain ischemia on cognitive function conditions is not studied enough.

Methods and results. To estimate influence of alternative prophylactic methods and methods of secondary brain ischemia on life quality in patients with intracranial aneurism hemorrhages after operation according to MMSE scale for cognitive function at hospital discharge was defined in 6 months and 2.5 years after treatment.

Conclusion. It was found that usage of prophylactic hypothermia and simvastatin didn't influence on cognitive function. Usage of therapeutic hypothermia in patients with complicated progressive intracranial aneurism hemorrhages improves cognitive functions in the post operative period, especially, function of orientation, memory, speech, an order of instructions execution, especially 2.5 years after operative treatment.

Key words: Intracranial Hemorrhages, Cognitive Aspects, Simvastatin, Hypothermia.

Zaporozhye medical journal 2015; №2 (89): 31-36

Когнітивні порушення після аневризматичних крововиливів наявні у 65-83\% пацієнтів [2,8,14]. Через 12 місяців після лікування значна кількість хворих має порушення пам'яті та швидкості реакцій, вираженість порушень залежить від різних периопераційних факторів: загального стану перед оперативним втручанням, розміру та локалізації аневризми, виду оперативного втручання $[8,10,11]$. Через 5 років після субарахноїдального крововиливу (САК) основними когнітивними порушеннями є порушення пам'яті та психічні розлади, що призводять до трагічних подій (опікові травми, дорожньо-транспортні пригоди) $[1,5,12]$. Вплив методів запобігання та лікування вторинної ішемії мозку, зокрема симвастатину та гіпотермії, на стан когнітивних функцій вивчений недостатньо і є актуальною проблемою $[4,7,9]$.

\section{Мета роботи}

Дослідити якість життя пацієнтів з інтракраніальними аневризматичними крововиливами при виписуванні зі стаціонару, через 6 місяців і 2,5 року після оперативного втручання при застосуванні альтернативних методів запобігання та лікування вторинної ішемії головного мозку.

\section{Паціснти і методи дослідження}

У дослідження залучили 328 пацієнтів з інтракраніальними аневризматичними крововиливами, які перебували на лікуванні в КЗ «Обласна клінічна лікарня ім. I.I. Мечникова» з 2005 до 2013 р. 257 пацієнтам здійснили інтракраніальне оперативне втручання - кліпування артеріальної аневризми, 71 хворого оперували ендоваскулярним методом.

(ㄱ С. О. Дудукіна, 2015 
Альтернативними методами запобігання та лікування вторинної ішемії мозку вважали профілактичну (ПГ) та терапевтичну (ТГ) системну гіпотермію та використання симвастатину (C).

Для запобігання розвитку вторинної ішемії мозку в 48 пацієнтів із рівнем свідомості 14-15 балів за шкалою коми Глазго (GCS) при інтракраніальному втручанні використовували профілактичну гіпотермію (ПГ-1). Контрольною для ПГ вважали групу із 211 пацієнтів з аналогічним початковим рівнем свідомості, яких оперували в умовах нормотермії (ПГ-0). Під час ендоваскулярного оперативного втручання ПГ не використовували (ПГ-2).

Симвастатин у дозі 80 мг на добу (C1) призначали 43 пацієнтам з ознаками артеріального судинного спазму. Контрольною вважали групу із 121 пацієнта 3 проявами $\mathrm{ACC}$, яким симвастатин не призначали (C0). Пацієнти без ACC не потребували призначення статинів (C2).

Для лікування внутрішньочерепної гіпертензії та вторинної ішемії мозку у 29 пацієнтів з ускладненнями в післяопераційному періоді використовували терапевтичну гіпотермію (ТГ1). Контрольною групою для ТГ вважали групу з 74 пацієнтів 3 аналогічними ускладненнями, яких лікували в умовах нормотермії (ТГ0). Пацієнтам без ішемічних ускладнень ТГ не призначали (ТГ2).

Гіпотермію проводили за допомогою апарата Blanketrol II компанії Cincinnati Sub-Zero за модифікованою методикою Gal R. [18]. Профілактична гіпотермія тривала до моменту кліпування аневризми. Терапевтична гіпотермія продовжувалася 48 годин. Безпосередні результати лікування оцінювали на момент завершення стаціонарного лікування, через 30 діб і 6 місяців після виписування за шкалою наслідків Глазго (GOS) [3].

Для класифікації безпосередніх результатів лікування умовно «добрими» вважали показники хворих з оцінкою за шкалою GOS 4 i 5 балів, «поганими» - 1, 2, 3 бали. Для оцінювання прогностичної цінності альтернативних методів щодо загальних результатів лікування використовували відношення шансів (OR) [2]. Віддалені результати лікування оцінювали за модифікованою шкалою Rankin [12]. Когнітивні порушення та здатність до комунікації оцінювали за допомогою шкали MMSE [6]. Середні значення показників когнітивних функцій порівнювали за t-критерієм Стьюдента [2].

\section{Результати та їх обговорення}

Визначаючи вплив альтернативних методів запобігання та лікування вторинної ішемії мозку на стан когнітивних функцій, виявили, що при виписуванні зі стаціонару середній бал за MMSE в пацієнтів, яким призначили ПГ, суттєво не відрізнявся від такого при виконанні операцій в умовах нормотермії, а також у тих пацієнтів, яких оперували ендоваскулярним методом. Детальний аналіз показав, що середні бали за кожною функцією також суттєво не відрізнялись (табл. 1).

Аналогічну картину визначили через 6 місяців після лікування (табл. 2).

Таблиияя 1

Стан когнітивних функцій при застосуванні профілактичної гіпотермії у хворих

з інтракраніальними аневризматичними крововиливами при виписуванні зі стаціонару (бали)

\begin{tabular}{|c|c|c|c|c|c|c|c|c|c|c|c|}
\hline & \multicolumn{2}{|c|}{ Усі пацієнти } & \multicolumn{2}{|c|}{ ПГ 0} & \multicolumn{2}{|c|}{ ПГ 1} & \multicolumn{2}{|c|}{ ПГ 2} & \multirow{2}{*}{$\mathrm{p}_{0-1}$} & \multirow{2}{*}{$\mathrm{p}_{0-2}$} & \multirow{2}{*}{$p_{1-2}$} \\
\hline & $\mathrm{M}$ & $\mathrm{m}$ & $\mathrm{M}$ & $\mathrm{m}$ & $M$ & $\mathrm{~m}$ & $M$ & $\mathrm{~m}$ & & & \\
\hline Орієнтир - час & 3,94 & 0,08 & 3,93 & 0,11 & 3,80 & 0,21 & 4,08 & 0,15 & 0,61 & 0,45 & 0,28 \\
\hline Орієнтир - місце & 3,88 & 0,08 & 3,88 & 0,11 & 3,80 & 0,20 & 3,95 & 0,16 & 0,76 & 0,70 & 0,55 \\
\hline Сприйняття & 2,48 & 0,05 & 2,43 & 0,07 & 2,52 & 0,12 & 2,57 & 0,10 & 0,55 & 0,29 & 0,76 \\
\hline Концентрація уваги та рахування & 3,24 & 0,09 & 3,25 & 0,12 & 3,02 & 0,25 & 3,39 & 0,15 & 0,38 & 0,52 & 0,19 \\
\hline Пам'ять & 2,06 & 0,06 & 2,06 & 0,08 & 1,89 & 0,16 & 2,15 & 0,12 & 0,32 & 0,53 & 0,18 \\
\hline Мовлення & 1,89 & 0,07 & 1,87 & 0,09 & 1,94 & 0,15 & 1,92 & 0,14 & 0,73 & 0,75 & 0,96 \\
\hline 3-етапна команда & 2,35 & 0,05 & 2,35 & 0,07 & 2,26 & 0,14 & 2,42 & 0,09 & 0,55 & 0,60 & 0,34 \\
\hline Читання & 1,82 & 0,06 & 1,80 & 0,08 & 1,76 & 0,15 & 1,89 & 0,11 & 0,81 & 0,53 & 0,47 \\
\hline MMSE & 21,66 & 0,46 & 21,57 & 0,61 & 21,00 & 1,18 & 22,37 & 0,77 & 0,67 & 0,47 & 0,31 \\
\hline
\end{tabular}

Примітка: $\mathrm{p}$ - рівень значущості.

Таблиияя 2

Стан когнітивних функцій при застосуванні профілактичної гіпотермії у хворих 3 інтракраніальними аневризматичними крововиливами через 6 місяців після оперативного втручання (бали)

\begin{tabular}{|c|c|c|c|c|c|c|c|c|c|c|c|}
\hline & \multicolumn{2}{|c|}{ Усі пацієнти } & \multicolumn{2}{|c|}{ ПГ 0} & \multicolumn{2}{|c|}{ ПГ 1} & \multicolumn{2}{|c|}{ ПГ 2} & \multirow[b]{2}{*}{$p_{0-1}$} & \multirow[b]{2}{*}{$p_{0-2}$} & \multirow[b]{2}{*}{$p_{1-2}$} \\
\hline & $\mathrm{M}$ & $\mathrm{m}$ & $\mathrm{M}$ & $\mathrm{m}$ & $\mathrm{M}$ & $m$ & $\mathrm{M}$ & $m$ & & & \\
\hline Орієнтир - час & 4,21 & 0,07 & 4,20 & 0,09 & 4,21 & 0,17 & 4,25 & 0,12 & 0,98 & 0,74 & 0,81 \\
\hline Орієнтир - місце & 4,12 & 0,06 & 4,12 & 0,08 & 4,11 & 0,15 & 4,14 & 0,12 & 0,99 & 0,90 & 0,91 \\
\hline Сприйняття & 2,63 & 0,04 & 2,60 & 0,05 & 2,66 & 0,09 & 2,68 & 0,08 & 0,63 & 0,46 & 0,88 \\
\hline Концентрація уваги та рахування & 3,45 & 0,07 & 3,44 & 0,09 & 3,41 & 0,19 & 3,53 & 0,14 & 0,89 & 0,63 & 0,61 \\
\hline Пам'ять & 2,18 & 0,05 & 2,18 & 0,07 & 2,09 & 0,14 & 2,27 & 0,11 & 0,57 & 0,47 & 0,31 \\
\hline Мовлення & 1,95 & 0,07 & 1,94 & 0,09 & 2,00 & 0,14 & 1,95 & 0,14 & 0,73 & 0,94 & 0,80 \\
\hline 3-етапна команда & 2,41 & 0,05 & 2,40 & 0,06 & 2,41 & 0,12 & 2,44 & 0,09 & 0,93 & 0,72 & 0,83 \\
\hline Читання & 1,97 & 0,06 & 1,94 & 0,08 & 1,98 & 0,14 & 2,07 & 0,10 & 0,80 & 0,35 & 0,59 \\
\hline MMSE & 22,92 & 0,38 & 22,80 & 0,51 & 22,86 & 0,93 & 23,32 & 0,66 & 0,96 & 0,59 & 0,68 \\
\hline
\end{tabular}

Примітка: $\mathrm{p}$ - рівень значущості. 
Через 2,5 року після операції відмінності визначили тільки в функції концентрації уваги та рахування (табл. 4). У хворих, яким використовували ПГ, функція концентрації уваги та рахування була кращою, ніж у пацієнтів, яких оперували ендоваскулярним методом, але з низьким рівнем значущості ( $\mathrm{p}=0,05)$. Отже, поряд із покращенням безпосередніх результатів лікування після операції $(\mathrm{OR}=2,528$ 95\% довірчий інтервал (ДІ) $[1,162 ; 5,501])$ та відсутністю впливу на результати лікування через 6 місяців $(\mathrm{OR}=0,237$ ДІ $[0,054 ; 1,035])$ та віддалені результати за Rankin $(\mathrm{OR}=0,787$ ДI $[0,393 ; 1,579])$ використання ПГ на когнітивні функції пацієнтів узагалі не впливало (табл. 3).

Використання С за наявності ознак ангіоспазму в пацієнтів з інтракраніальними аневризматичними крововиливами сприяло покращенню загальних результатів лікування. При застосуванні С в 3,2 раза більше хворих мали «добрі», ніж «погані» результати лікування за GOS при виписуванні зі стаціонару $(\mathrm{OR}=3,266$ ДІ $[1,508 ; 7,073])$; спостерігали втричі менше випадків розвитку ішемічного інсульту після оперативного втручання (OR=3,15 ДІ $[1,511 ; 6,568])$. Поряд із покращенням загальних результатів лікування стан когнітивних функцій при застосуванні С при виписуванні зі стаціонару суттєво не відрізнявся від показників при стандартній терапії. Так, при використанні С (табл. 4) незначно покращувались тільки функції орієнтиру: час $(\mathrm{p}=0,03) \mathrm{i}$ місце $(\mathrm{p}=0,03)$. У хворих без розвитку ангіоспазму загальний бал за MMSE та значення всіх когнітивних функцій за винятком пам'яті $(\mathrm{p}=0,11)$ були значно кращими (табл. 4).

Незважаючи на покращення всіх когнітивних функцій у загальній групі хворих через 6 місяців (табл. 5) та 2,5 року після лікування, позитивного впливу $\mathrm{C}$ на когнітивні функції не виявили (табл. б).

Використання ТГ у післяопераційному періоді в пацієнтів із вираженою внутрішньочерепною гіпертензією та вторинною ішемією мозку призводила до загального покращення результатів лікування. Порівнюючи результати лікування пацієнтів у групах ТГ0 та ТГ1 за категоріями «добрий» i «поганий» значущих розбіжностей не виявили $(\mathrm{OR}=2,036$ $[0,691 ; 6,000])$, але ТГ сприяла покращенню неврологічних функцій і зменшенню летальності $(\mathrm{p}=0,000001)$. Розбіжностей за загальним станом когнітивних функцій і кожної $з$ них при виписуванні зі стаціонару не встановили. У хворих без ускладнень загальний стан когнітивних функцій і стан кожної з них був значно кращий (табл.7).

Таблиия 3

Стан когнітивних функцій при застосуванні профілактичної гіпотермії у хворих 3 інтракраніальними аневризматичними крововиливами через 2,5 року після оперативного втручання (бали)

\begin{tabular}{|c|c|c|c|c|c|c|c|c|c|c|c|}
\hline & \multicolumn{2}{|c|}{ Усі пацієнти } & \multicolumn{2}{|c|}{ ПГ 0} & \multicolumn{2}{|c|}{ ПГ 1} & \multicolumn{2}{|c|}{ ПГ 2} & \multirow[b]{2}{*}{$p_{0-1}$} & \multirow{2}{*}{$\mathrm{p}_{0-2}$} & \multirow{2}{*}{$\mathrm{p}_{1-2}$} \\
\hline & $\mathrm{M}$ & $\mathrm{m}$ & $M$ & $m$ & $\mathrm{M}$ & $m$ & $\mathrm{M}$ & $\mathrm{m}$ & & & \\
\hline Орієнтир - час & 4,60 & 0,05 & 4,54 & 0,07 & 4,73 & 0,10 & 4,67 & 0,07 & 0,18 & 0,27 & 0,62 \\
\hline Орієнтир - місце & 4,60 & 0,05 & 4,57 & 0,06 & 4,71 & 0,11 & 4,60 & 0,07 & 0,31 & 0,78 & 0,41 \\
\hline Сприйняття & 2,91 & 0,02 & 2,89 & 0,03 & 2,93 & 0,04 & 2,93 & 0,03 & 0,59 & 0,48 & 0,94 \\
\hline Концентрація уваги та рахування & 4,25 & 0,06 & 4,24 & 0,07 & 4,49 & 0,13 & 4,12 & 0,12 & 0,11 & 0,41 & 0,05 \\
\hline Пам'ять & 2,60 & 0,04 & 2,56 & 0,05 & 2,78 & 0,09 & 2,57 & 0,10 & 0,06 & 0,93 & 0,13 \\
\hline Мовлення & 2,47 & 0,05 & 2,45 & 0,06 & 2,68 & 0,08 & 2,40 & 0,11 & 0,06 & 0,67 & 0,05 \\
\hline 3-етапна команда & 2,50 & 0,05 & 2,50 & 0,06 & 2,56 & 0,12 & 2,48 & 0,10 & 0,61 & 0,90 & 0,60 \\
\hline Читання & 2,44 & 0,05 & 2,42 & 0,06 & 2,54 & 0,12 & 2,43 & 0,10 & 0,40 & 0,94 & 0,49 \\
\hline MMSE & 26,37 & 0,26 & 26,17 & 0,35 & 27,42 & 0,62 & 26,21 & 0,46 & 0,11 & 0,95 & 0,11 \\
\hline
\end{tabular}

Примітка: р - рівень значущості.

Таблиия 4

Стан когнітивних функцій при застосуванні симвастатину у хворих з інтракраніальними аневризматичними крововиливами 3 ангіоспазмом при виписуванні зі стаціонару (бали)

\begin{tabular}{|c|c|c|c|c|c|c|c|c|c|c|c|}
\hline & \multicolumn{2}{|c|}{ Усі пацієнти } & \multicolumn{2}{|c|}{$\mathrm{CO}$} & \multicolumn{2}{|c|}{ C1 } & \multicolumn{2}{|c|}{$\mathrm{C} 2$} & \multirow{2}{*}{$p_{0-1}$} & \multirow{2}{*}{$\mathrm{p}_{0-2}$} & \multirow{2}{*}{$p_{1-2}$} \\
\hline & $\mathrm{M}$ & $\mathrm{m}$ & $\mathrm{M}$ & $\mathrm{m}$ & $\mathrm{M}$ & $\mathrm{m}$ & $\mathrm{M}$ & $\mathrm{m}$ & & & \\
\hline Орієнтир - час & 3,94 & 0,08 & 3,41 & 0,17 & 4,05 & 0,22 & 4,24 & 0,09 & 0,03 & 0,000003 & 0,39 \\
\hline Орієнтир - місце & 3,88 & 0,08 & 3,33 & 0,17 & 3,97 & 0,22 & 4,20 & 0,09 & 0,03 & 0,000001 & 0,28 \\
\hline Сприйняття & 2,48 & 0,05 & 2,18 & 0,11 & 2,49 & 0,14 & 2,65 & 0,06 & 0,12 & 0,00004 & 0,24 \\
\hline Концентрація уваги та рахування & 3,24 & 0,09 & 2,82 & 0,17 & 3,16 & 0,25 & 3,52 & 0,10 & 0,29 & 0,0003 & 0,15 \\
\hline Пам'ять & 2,06 & 0,06 & 1,93 & 0,12 & 2,03 & 0,14 & 2,14 & 0,08 & 0,64 & 0,11 & 0,50 \\
\hline 3-етапна команда & 2,35 & 0,05 & 2,14 & 0,10 & 2,43 & 0,12 & 2,46 & 0,06 & 0,10 & 0,005 & 0,84 \\
\hline Читання & 1,82 & 0,06 & 1,60 & 0,11 & 1,84 & 0,15 & 1,94 & 0,08 & 0,25 & 0,009 & 0,54 \\
\hline MMSE & 21,66 & 0,46 & 18,85 & 0,92 & 21,78 & 1,15 & 23,33 & 0,52 & 0,08 & 0,000008 & 0,20 \\
\hline
\end{tabular}

Примітка: $\mathrm{p}$ - рівень значущості.

(c) С. О. Дудукіна, 2015 
Табличя 5

Стан когнітивних функцій при застосуванні симвастатину у хворих 3 інтракраніальними аневризматичними крововиливами 3 ангіоспазмом через 6 місяців після оперативного втручання (бали)

\begin{tabular}{|c|c|c|c|c|c|c|c|c|c|c|c|}
\hline & \multicolumn{2}{|c|}{ Усі пацієнти } & \multicolumn{2}{|c|}{$\mathrm{CO}$} & \multicolumn{2}{|c|}{ C1 } & \multicolumn{2}{|c|}{$\mathrm{C} 2$} & \multirow{2}{*}{$\mathrm{p}_{0-1}$} & \multirow{2}{*}{$\mathrm{p}_{0-2}$} & \multirow{2}{*}{$p_{1-2}$} \\
\hline & $\mathrm{M}$ & $\mathrm{m}$ & $M$ & $\mathrm{~m}$ & $M$ & $\mathrm{~m}$ & $M$ & $\mathrm{~m}$ & & & \\
\hline Орієнтир - час & 4,21 & 0,07 & 3,82 & 0,15 & 4,27 & 0,17 & 4,43 & 0,07 & 0,07 & 0,00004 & 0,34 \\
\hline Орієнтир - місце & 4,12 & 0,06 & 3,77 & 0,13 & 4,22 & 0,15 & 4,30 & 0,07 & 0,05 & 0,0001 & 0,60 \\
\hline Сприйняття & 2,63 & 0,04 & 2,44 & 0,09 & 2,65 & 0,09 & 2,73 & 0,05 & 0,16 & 0,002 & 0,43 \\
\hline Концентрація уваги та рахування & 3,45 & 0,07 & 3,08 & 0,15 & 3,51 & 0,19 & 3,66 & 0,09 & 0,09 & 0,0003 & 0,46 \\
\hline Пам'ять & 2,18 & 0,05 & 2,07 & 0,11 & 2,11 & 0,14 & 2,27 & 0,07 & 0,83 & 0,09 & 0,29 \\
\hline Мовлення & 1,95 & 0,07 & 1,57 & 0,13 & 1,84 & 0,17 & 2,20 & 0,08 & 0,24 & 0,00001 & 0,04 \\
\hline 3-етапна команда & 2,41 & 0,05 & 2,25 & 0,09 & 2,46 & 0,12 & 2,49 & 0,06 & 0,20 & 0,03 & 0,83 \\
\hline Читання & 1,97 & 0,06 & 1,77 & 0,11 & 2,03 & 0,14 & 2,07 & 0,07 & 0,19 & 0,02 & 0,77 \\
\hline MMSE & 22,92 & 0,38 & 20,77 & 0,80 & 23,08 & 0,93 & 24,15 & 0,43 & 0,09 & 0,00006 & 0,28 \\
\hline
\end{tabular}

Примітка: $\mathrm{p}$ - рівень значущості.

Таблиия 6

Стан когнітивних функцій при застосуванні симвастатину у хворих з інтракраніальними аневризматичними крововиливами 3 ангіоспазмом через 2,5 року після оперативного втручання (бали)

\begin{tabular}{|c|c|c|c|c|c|c|c|c|c|c|c|}
\hline & \multicolumn{2}{|c|}{ Усі пацієнти } & \multicolumn{2}{|c|}{ C 0} & \multicolumn{2}{|c|}{ C 1} & \multicolumn{2}{|c|}{ C 2} & \multirow{2}{*}{$\mathrm{p}_{0-1}$} & \multirow{2}{*}{$\mathrm{p}_{0-2}$} & \multirow[b]{2}{*}{$p_{1-2}$} \\
\hline & $\mathrm{M}$ & $\mathrm{m}$ & $\mathrm{M}$ & $\mathrm{m}$ & $\mathrm{M}$ & $\mathrm{m}$ & $\mathrm{M}$ & $\mathrm{m}$ & & & \\
\hline Орієнтир - час & 4,60 & 0,05 & 4,47 & 0,10 & 4,57 & 0,14 & 4,68 & 0,05 & 0,57 & 0,04 & 0,39 \\
\hline Орієнтир - місце & 4,60 & 0,05 & 4,47 & 0,10 & 4,63 & 0,12 & 4,67 & 0,05 & 0,37 & 0,05 & 0,72 \\
\hline Сприйняття & 2,91 & 0,02 & 2,84 & 0,04 & 2,97 & 0,03 & 2,93 & 0,03 & 0,07 & 0,07 & 0,44 \\
\hline Концентрація уваги та рахунок & 4,25 & 0,06 & 4,10 & 0,11 & 4,40 & 0,17 & 4,30 & 0,07 & 0,13 & 0,10 & 0,55 \\
\hline Пам'ять & 2,60 & 0,04 & 2,52 & 0,09 & 2,51 & 0,12 & 2,66 & 0,05 & 0,98 & 0,13 & 0,23 \\
\hline Мовлення & 2,47 & 0,05 & 2,34 & 0,09 & 2,46 & 0,13 & 2,56 & 0,06 & 0,44 & 0,03 & 0,46 \\
\hline 3-етапна команда & 2,50 & 0,05 & 2,36 & 0,09 & 2,54 & 0,13 & 2,58 & 0,06 & 0,25 & 0,03 & 0,79 \\
\hline Читання & 2,44 & 0,05 & 2,30 & 0,09 & 2,46 & 0,13 & 2,52 & 0,06 & 0,34 & 0,04 & 0,64 \\
\hline MMSE & 26,37 & 0,26 & 25,40 & 0,53 & 26,54 & 0,71 & 26,90 & 0,31 & 0,23 & 0,01 & 0,62 \\
\hline
\end{tabular}

Примітка: р - рівень значущості.

Таблиия 7

Стан когнітивних функцій при застосуванні терапевтичної гіпотермії у хворих з ускладненими інтракраніальними аневризматичними крововиливами при виписуванні зі стаціонару (бали)

\begin{tabular}{|c|c|c|c|c|c|c|c|c|c|c|c|}
\hline & \multicolumn{2}{|c|}{ Усі пацієнти } & \multicolumn{2}{|c|}{ ТГ 0} & \multicolumn{2}{|c|}{ ТГ 1} & \multicolumn{2}{|c|}{$\mathrm{TГ} 2$} & \multirow[b]{2}{*}{$\mathrm{p}_{0-1}$} & \multirow[b]{2}{*}{$\mathrm{p}_{0-2}$} & \multirow[b]{2}{*}{$p_{1-2}$} \\
\hline & M & $\mathrm{m}$ & M & $\mathrm{m}$ & M & $\mathrm{m}$ & M & $\mathrm{m}$ & & & \\
\hline Орієнтир - час & 3,94 & 0,08 & 2,43 & 0,24 & 2,50 & 0,33 & 4,36 & 0,07 & 0,87 & 0 & 0 \\
\hline Орієнтир - місце & 3,88 & 0,08 & 2,51 & 0,28 & 2,69 & 0,34 & 4,24 & 0,07 & 0,68 & 0 & 0 \\
\hline Сприйняття & 2,48 & 0,05 & 1,41 & 0,18 & 1,50 & 0,19 & 2,76 & 0,04 & 0,72 & 0 & 0 \\
\hline Концентрація уваги та рахування & 3,24 & 0,09 & 1,65 & 0,26 & 1,92 & 0,33 & 3,66 & 0,08 & 0,51 & 0 & 0 \\
\hline Пам'ять & 2,06 & 0,06 & 1,14 & 0,19 & 1,42 & 0,22 & 2,28 & 0,06 & 0,33 & 0 & 0,000005 \\
\hline Мовлення & 1,89 & 0,07 & 0,78 & 0,18 & 0,77 & 0,22 & 2,20 & 0,06 & 0,96 & 0 & 0 \\
\hline 3-етапна команда & 2,35 & 0,05 & 1,54 & 0,16 & 1,81 & 0,20 & 2,55 & 0,05 & 0,29 & 0 & 0,000004 \\
\hline Читання & 1,82 & 0,06 & 0,87 & 0,14 & 0,89 & 0,18 & 2,08 & 0,06 & 0,93 & 0 & 0 \\
\hline MMSE & 21,66 & 0,46 & 12,32 & 1,27 & 13,50 & 1,67 & 24,13 & 0,37 & 0,57 & 0 & 0 \\
\hline
\end{tabular}

Примітка: р - рівень значущості.

Згідно з аналізом OR, ризик «добрих» $\mathrm{i}$ «поганих» результатів через 6 місяців $(\mathrm{OR}=1,314$ ДІ $[0,479 ; 3,605])$ і через 2,5 року $(\mathrm{OR}=0,354$ ДI $[0,088 ; 1,43])$ лікування був однаковий незалежно від застосування ТГ. Однак, незважаючи на відсутність розбіжностей у результатах лікування за категорією «добрий»/«поганий», через 6 місяців після лікування у групі пацієнтів із ТГ спостерігали незначне поліпшення загального стану когнітивних функцій за MMSE $(\mathrm{p}=0,04)$ та окремо функцій орієнтир - час $(\mathrm{p}=0,04)$, концентрації уваги та рахування $(p=0,02)$, пам'яті $(p=0,01)$. Стан усіх когнітивних функцій у пацієнтів без ускладнень був значно кращим (табл. 8). 
Стан когнітивних функцій при застосуванні терапевтичної гіпотермії у хворих з ускладненими інтракраніальними аневризматичними крововиливами через 6 місяців після лікування (бали)

\begin{tabular}{|c|c|c|c|c|c|c|c|c|c|c|c|}
\hline & \multicolumn{2}{|c|}{ Усі пацієнти } & \multicolumn{2}{|c|}{ ТГ 0} & \multicolumn{2}{|c|}{ ТГ 1} & \multicolumn{2}{|c|}{ ТГ 2} & \multirow{2}{*}{$\mathrm{p}_{0-1}$} & \multirow{2}{*}{$\mathrm{p}_{0-2}$} & \multirow{2}{*}{$p_{1-2}$} \\
\hline & $\mathrm{M}$ & $\mathrm{m}$ & $\mathrm{M}$ & $\mathrm{m}$ & $\mathrm{M}$ & $\mathrm{m}$ & $\mathrm{M}$ & $\mathrm{m}$ & & & \\
\hline Орієнтир - час & 4,21 & 0,07 & 2,83 & 0,22 & 3,57 & 0,25 & 4,51 & 0,06 & 0,04 & 0 & 0,000001 \\
\hline Орієнтир - місце & 4,12 & 0,06 & 3,03 & 0,22 & 3,52 & 0,21 & 4,37 & 0,06 & 0,13 & 0 & 0,000005 \\
\hline Сприйняття & 2,63 & 0,04 & 1,83 & 0,15 & 2,04 & 0,15 & 2,82 & 0,03 & 0,35 & 0 & 0 \\
\hline Концентрація уваги та рахунок & 3,45 & 0,07 & 2,06 & 0,20 & 2,83 & 0,26 & 3,75 & 0,07 & 0,02 & 0 & 0,00004 \\
\hline Пам'ять & 2,18 & 0,05 & 1,33 & 0,16 & 1,96 & 0,17 & 2,35 & 0,05 & 0,01 & 0 & 0,02 \\
\hline Мовлення & 1,95 & 0,07 & 0,83 & 0,18 & 1,04 & 0,23 & 2,23 & 0,06 & 0,47 & 0 & 0 \\
\hline 3-етапна команда & 2,41 & 0,05 & 1,56 & 0,15 & 2,00 & 0,19 & 2,60 & 0,05 & 0,07 & 0 & 0,00009 \\
\hline Читання & 1,97 & 0,06 & 1,06 & 0,14 & 1,17 & 0,19 & 2,21 & 0,05 & 0,61 & 0 & 0 \\
\hline MMSE & 22,92 & 0,38 & 14,53 & 1,13 & 18,13 & 1,19 & 24,84 & 0,32 & 0,04 & 0 & 0 \\
\hline
\end{tabular}

Примітка: р - рівень значущості.

Стан когнітивних функцій при застосуванні терапевтичної гіпотермії у хворих з ускладненими інтракраніальними аневризматичними крововиливами через 2,5 року після лікування (бали)

\begin{tabular}{|c|c|c|c|c|c|c|c|c|c|c|c|}
\hline & \multicolumn{2}{|c|}{ Усі пацієнти } & \multicolumn{2}{|c|}{ ТГ 0} & \multicolumn{2}{|c|}{ ТГ 1} & \multicolumn{2}{|c|}{ ТГ 2} & \multirow{2}{*}{$\mathrm{p}_{0-1}$} & \multirow{2}{*}{$\mathrm{p}_{0-2}$} & \multirow{2}{*}{$p_{1-2}$} \\
\hline & $\mathrm{M}$ & $\mathrm{m}$ & $\mathrm{M}$ & $\mathrm{m}$ & $M$ & $\mathrm{~m}$ & $\mathrm{M}$ & $\mathrm{m}$ & & & \\
\hline Орієнтир - час & 4,60 & 0,05 & 3,94 & 0,18 & 4,77 & 0,09 & 4,69 & 0,05 & 0,0008 & 0 & 0,58 \\
\hline Орієнтир - місце & 4,60 & 0,05 & 4,03 & 0,18 & 4,91 & 0,06 & 4,66 & 0,05 & 0,0004 & 0,000003 & 0,08 \\
\hline Сприйняття & 2,91 & 0,02 & 2,74 & 0,10 & 2,86 & 0,08 & 2,94 & 0,02 & 0,35 & 0,0006 & 0,20 \\
\hline Концентрація уваги та рахування & 4,25 & 0,06 & 3,65 & 0,17 & 4,05 & 0,21 & 4,37 & 0,06 & 0,15 & 0,00001 & 0,09 \\
\hline Пам'ять & 2,60 & 0,04 & 2,12 & 0,14 & 2,73 & 0,12 & 2,66 & 0,05 & 0,003 & 0,00002 & 0,65 \\
\hline Мовлення & 2,47 & 0,05 & 1,74 & 0,14 & 2,46 & 0,13 & 2,60 & 0,05 & 0,0009 & 0 & 0,33 \\
\hline 3-етапна команда & 2,50 & 0,05 & 1,79 & 0,13 & 2,55 & 0,13 & 2,62 & 0,05 & 0,0002 & 0 & 0,63 \\
\hline читання & 2,44 & 0,05 & 1,62 & 0,11 & 2,41 & 0,13 & 2,58 & 0,05 & 0,00003 & 0 & 0,27 \\
\hline MMSE & 26,37 & 0,26 & 21,62 & 0,82 & 26,73 & 0,63 & 27,13 & 0,26 & 0,00004 & 0 & 0,62 \\
\hline
\end{tabular}

Примітка: $\mathrm{p}$ - рівень значущості.

Через 2,5 року після лікування загальний стан когнітивних функцій у групі ТГ наблизився до такого стану в пацієнтів без ускладнень і був кращим, ніж у пацієнтів без ТГ. Значні розбіжності були в усіх функціях, крім сприйняття, концентрації уваги та рахування (табл. 9).

\section{Висновки}

Використання профілактичної гіпотермії не впливає на стан когнітивних функцій у пацієнтів з інтракраніальними аневризматичними крововиливами після оперативного втручання.

Використання симвастатину в дозі 80 мг на добу в пацієнтів з інтракраніальними аневризматичними крововиливами та ангіоспазмом не впливає на стан когнітивних функцій після операції.

Використання терапевтичної гіпотермії в пацієнтів інтракраніальними аневризматичними крововиливами, що ускладнились вторинною ішемією мозку та внутрішньочерепною гіпертензією, призводить до поліпшення когнітивних функцій, зокрема функції орієнтиру, пам'яті, мовленнєвих функцій, читання та послідовності виконання вправ, особливо через 2,5 року після оперативного втручання.

Перспективи подальших досліджень. Результати аналізу якості життя після оперативного втручання та впливу альтернативних методів запобігання та лікування вторинної ішемії у хворих з інтракраніальними аневризматичними крововиливами на стан когнітивних функцій можуть бути предметом досліджень психологів і психіатрів під час розробки додаткових заходів щодо запобігання розвитку когнітивних порушень і методів їх лікування.

T.A. Schweizer // Stroke. - 2010. -Vol. 41(8). - P. 519-536.

Список літератури

1. Крылов В.В. Отдаленные результаты хирургического лечения аневризм головного мозга в остром периоде кровоизлияния / В.В. Крылов, С.А. Буров // Нейрохирургия. - 2000. - №4. - С. 61-66

2. Наследов A. SPSS 19: профессиональный статистический анализ данных / А. Наследов. - СПб. : Питер, 2011. - 400 c.

3. Al-Khindi T. Cognitive and functional outcome after aneurysmal subarachnoid hemorrhage / T. Al-Khindi, R.L. Macdonald,
Effects of intraoperative hypothermia on neuropsychological outcomes after intracranial aneurysm surgery / S.W. Anderson, M.M. Todd, B.J. Hindman, et al. // Ann Neurol. - 2006. - Vol. 60. - P. 518-527.

5. Chahal N. Cognitive and functional outcomes of 5-year subarachnoid haemorrhage survivors: comparison to matched healthy controls / N. Chahal, S. Barker-Collo, V. Feigin // Neuroepidemiology. - 2011. - №37(1). - P. 31-38.

(ㄱ С. О. Дудукіна, 2015 
6. Folstein M.F. «Mini-mental state». A practical method for grading the cognitive state of patients for the clinician / M.F. Folstein, S.E. Folstein, P.R. McHugh // Journal of psychiatric research. 1975. - №12(3). - P. 189-198.

7. Kirkpatrick P.J. Simvastatin in aneurysmal subarachnoid haemorrhage (STASH): a multicentre randomised phase 3 trial / P.J. Kirkpatrick, C.L. Turner, P.J. Hutchinson, et al. // Lancet Neurol. - 2014. - Vol.13. - №7. - P. 666-675.

8. Subarachnoid haemorrhage (SAH): long-term cognitive outcome in patients treated with surgical clipping or endovascular coiling / S.F. Latimer, F.C. Wilson, C.G. McCusker // Disabil Rehabil. 2013. - Vol. 35(10). - P. 845-850.

9. Lombard F. Simvastatin in subarachnoid haemorrhage: beyond the short-term / F. Lombard, G.W. Britz, D.S. Warner // The Lancet Neurology. - 2014. - Vol. 13. - №11. - P. 1073.

10. Ogden J.A. A prospective study of impairment of cognition and memory and recovery after subarachnoid hemorrhage / J.A. Ogden, E.W. Mee, M. Henning // Neurosurgery. - 1993. Vol. 33(4). - P. 572-586.

11. Comparison of postoperative cognitive function in patients undergoing surgery for ruptured and unruptured intracranial aneurysm / Y. Otawara, K. Ogasawara, Y. Kubo, et al. // Surg. Neurol. - 2009. - Vol. 72(6). - P. 592-595.

12. de Haan R.N. The Clinical Meaning of Rankin 'Handicap' Grades After Stroke / R. N. de Haan, M. Limburg, P. Bossuyt, et al. // Stroke. - 1995. - №26. - P. 2027-2030.

13. Rinkel G.J. Long-term outcomes of patients with aneurysmal subarachnoid haemorrhage / G.J. Rinkel, A. Algra // Lancet Neurology. - 2011. - №10(4). - P. 349-356.

14. Predictors of global cognitive impairment 1 year after subarachnoid hemorrhage / M.V. Springer, J.M. Schmidt, K.E. Wartenberg, et al. // Neurosurgery. - 2009. - №65(6). - P. 1043-1050.

\section{References}

1. Krylov, V. V., \& Burov, S. A. (2000) Otdalennye rezul taty khirurgicheskogo lecheniya anevrizm golovnogo mozga $\mathrm{v}$ ostrom periode krovoizliyaniya [Long-term results of surgical treatment of brain aneurysms in acute hemorrhage]. Nejrokhirurgiya, 4, 61-66. [in Russian].

2. Nasledov, A. (2011) SPSS 19: professional nyj statisticheskij analiz dannykh [SPSS 19: professional statistical analysis]. Saint Petersburg. [in Russian].

3. Al-Khindi, T., Macdonald, R. L., Schweizer, T. A. (2010) Cognitive and functional outcome after aneurysmal subarachnoid hemorrhage. Stroke, 41(8), 519-536. doi: 10.1161/ strokeaha.110.581975.
4. Anderson, S. W., Todd, M. M., Hindman, B. J., Clarke, W. R., Torner, J. C., Tranel, D., et al. (2006) Effects of intraoperative hypothermia on neuropsychological outcomes after intracranial aneurysm surgery. Ann Neurol, 60, 518-527. doi: 10.1002/ ana. 21018

5. Chahal, N., Barker-Collo, S., \& Feigin, V. (2011) Cognitive and functional outcomes of 5-year subarachnoid haemorrhage survivors: comparison to matched healthy controls. Neuroepidemiology, 37(1), 31-38. doi: 10.1159/000328647.

6. Folstein, M. F., Folstein, S. E., \& McHugh, P. R. (1975) «Minimental state». A practical method for grading the cognitive state of patients for the clinician. Journal of psychiatric research, 12(3), 189-198. doi: 10.1016/0022-3956(75)90026-6.

7. Kirkpatrick, P. J., Turner, C. L., Hutchinson, P. J., Smith, C., \& Murray, G. D. (2014) Simvastatin in aneurysmal subarachnoid haemorrhage (STASH): a multicentre randomised phase 3 trial. Lancet Neurol, 13(7), 666-675. doi: http://dx.doi.org/10.1016/ S1474-4422(14)70084-5.

8. Latimer, S. F., Wilson, F. C., McCusker, C. G., Caldwell, S. B., \& Rennie, I. (2013) Subarachnoid haemorrhage (SAH): long-term cognitive outcome in patients treated with surgical clipping or endovascular coiling. Disabil Rehabil., 35(10), 845-850. doi: 10.3109/09638288.2012.709909.

9. Lombard, F., Britz, G. W., \& Warner, D. S. (2014) Simvastatin in subarachnoid haemorrhage: beyond the short-term. The Lancet Neurology, 13(11), 1073. doi: 10.1016/S1474-4422(14)70229-7.

10. Ogden, J. A., Mee, E. W., \& Henning, M. (1993) A prospective study of impairment of cognition and memory and recovery after subarachnoid hemorrhage. Neurosurgery,_33(4), 572-586.

11. Otawara, Y., Ogasawara, K., Kubo, Y., Kashimura, H., Ogawa, A., \& Yamadate, K. (2009) Comparison of postoperative cognitive function in patients undergoing surgery for ruptured and unruptured intracranial aneurysm. Surg. Neurol., 72(6), 592-595. doi: 10.1016/j.surneu.2009.06.016.

12. de Haan, R. N., Limburg, M, Bossuyt, P, J., van der Meulen, J. \& Aaronson, N. (1995) The Clinical Meaning of Rankin 'Handicap' Grades After Stroke. Stroke, 26, 2027-2030. doi: 10.1161/01. STR.26.11.2027.

13. Rinkel, G. J, \& Algra, A. (2011) Long-term outcomes of patients with aneurysmal subarachnoid haemorrhage. The Lancet Neurology,_10(4), 349-356. doi: http://dx.doi.org/10.1016/S14744422(11)70017-5.

14. Springer, M. V., Schmidt, J. M., Wartenberg, K. E., Frontera, J. A., Badjatia, N., \& Mayer, S. A. (2009) Predictors of global cognitive impairment 1 year after subarachnoid hemorrhage. Neurosurgery, 65(6), 1043-1050. doi: 10.1227/01.NEU.0000359317.15269.20.

\section{Відомості про автора:}

Дудукіна С.О., к. мед. н., лікар-анестезіолог, КЗ «Дніпропетровська обласна клінічна лікарня ім. І.І. Мечникова», заслужений лікар України, E-mail: dudukina@ukr.net.

\section{Сведения об авторе:}

Дудукина С.А., к. мед. н., врач-анестезиолог, КП «Днепропетровская областная клиническая больница им. И.И. Мечникова», заслуженный врач Украины, E-mail: dudukina@ukr.net.

Information about author:

Dudukina S.O., MD, PhD, anesthesiologist, Neuro Intensive Care Unit, Dnipropetrovsk Mechnicov Hospital, E-mail: dudukina@ukr.net. 